\title{
Correction to: Geochemical contamination in the Densu Estuary, Gulf of Guinea, Ghana
}

\author{
Lailah Gifty Akita $^{1}$ (D) Jürgen Laudien ${ }^{3}$ • Elvis Nyarko ${ }^{1,2}$
}

Published online: 22 August 2020

(C) Springer-Verlag GmbH Germany, part of Springer Nature 2020

\section{Correction to: Environmental Science and Pollution Research https://oi.org/10.1007/s11356-020-10035-4}

The correct equations are presented below:

The pollution load index (PLI) is determined by the formula (Tomlinson et al. 1980):

$\mathrm{PLI}=\mathrm{n} \sqrt{ }\left(\mathrm{CF}_{1} \times \mathrm{CF}_{2} \times \mathrm{CF}_{3} \ldots . \times \mathrm{CF}_{\mathrm{n}}\right)$.

Where,

The enrichment factor is calculated using the formula (Ergin et al. 1991):

$\mathrm{EF}=(\mathrm{X} / \mathrm{Fe})_{\text {sediment }} /(\mathrm{X} / \mathrm{Fe})_{\mathrm{Background} \text { reference }}$

$\begin{array}{lll}\mathrm{CF} & = & \mathrm{C}_{\text {metal }} / \mathrm{C}_{\text {background reference }} \\ \mathrm{CF} & = & \text { contamination factor, } \mathrm{n}=\text { number } \\ & & \text { of metals }\end{array}$

Where $\mathrm{X} / \mathrm{Fe}$ is the ratio of the concentrations of metal $\mathrm{X}$ (element) to $\mathrm{Fe}$ (normalized metal or element).

Contamination factor (CF) is a ratio of the concentration of a metal in sediment to natural abundance (pre-industrial reference value for the same metal):

$\mathrm{CF}=\mathrm{C}_{\text {metal }} / C_{\text {background }}$ reference

Publisher's note Springer Nature remains neutral with regard to jurisdictional claims in published maps and institutional affiliations.

The online version of the original article can be found at https://doi.org/ 10.1007/s11356-020-10035-4

Lailah Gifty Akita

lailah.akita@gmail.com

1 Department of Marine and Fisheries Sciences, University of Ghana, P. O. Box LG 99, Legon, Accra, Ghana

2 Regional Maritime University, P. O. Box GP 1115, Accra, Ghana

3 Alfred Wegner Institute Helmholtz Centre of Polar and Marine Research, Am Alten Hafen 26, 27568 Bremerhaven, Germany 